of the Council, they must be sent to the assistant general secretary at least one month before the meeting of the Association. The decision of the Council on the claims of any member of the Association to be placed on the list of the General Committee to be final.

CLASS B. -TEMPORARY MEMBERS

3. The president for the time being, or, in his absence, one delegate representing him, of any scientific society publishing transactions. Claims under this rule to be sent to the assistant general secretary before the opening of the meeting.

4. Office-bearers for the time being, or delegates, altogether not exceeding three, from scientific institutions established in the place of meeting. Claims under this rule to be approved by the local secretaries before the opening of the meeting.

5. Foreigners and other individuals whose assistance is desired, and who are specially nominated in writing, for the meeting of the year, by the president and general secretaries.

6 . Vice-presidents and secretaries of sections."

\section{SECTIONAL PROCEEDINGS}

Section A.-Mathematical and Physical Science.-President, Prof. J. Clerk Maxwell, F.R.S.

The president delivered the following address:-

At several of the recent meetings of the British Association the varied and important business of the Mathematical and Physical Section has been introduced by an Address, the subject of which has been left to the selection of the president for the time being. The perplexing duty of choosing a subject has not, however, fallen to me. Professor Sylvester, the president of Section $\mathrm{A}$ at the Exeter meeting, gave us a noble vindication of pure mathematics by laying bare, as it were, the very working of the mathematical mind, and setting before us, not the array of symbols and brackets which form the armoury of the mathematician, or the dry results which are only the monuments of his conquests, but the mathematician himself, with all his human faculties directed by his professional sagacity to the pursuit, apprehension, and exhibition of that ideal harmony which he feels to be the root of all knowledge, the fountain of all pleasure, and the condition of all action. The mathematician has, above all things, an eye for symmetry ; and Professor Sylvester has not only recognised the symmetry formed by the combination of his own subject with those of the former presidents, but has pointed out the duties of his successor in the following characteristic note :-

"Mr. Spottiswoode favoured the Section, in his opening address, with a combined history of the progress of mathematics and physics; Dr. Tyndall's address was virtually on the limits of physical philosophy; the one here in print," says Professor Sylvester, "is an attempted faint adumbration of the nature of mathematical science in the alstract. What is wanting (like a fourth sphere resting on three others in contact) to build up the ideal pyramid is a discourse on the relation of the two branches (mathematies and physics) to, and their action and reaction upon, one another-a magnificent theme, with which it is to be hoped that some future president of Section $\mathrm{A}$ will crown the edifice, and make the tetralogy (symbolisable by $\mathrm{A}+\mathrm{A}^{\prime}, \mathrm{A}, \mathrm{A}^{\prime}, \mathrm{AA}^{\prime}$ ) complete."

The theme thus distinctly laid down for his successor by our late President is indeed a magnificent one, far too magnificent for any efforts of mine to realise. I have endeavoured to follow $\mathrm{Mr}$. Spottiswoode, as with far-reaching vision he distinguishes the systems of science into which phenomena, our knowledge of which is still in the nebulous stage, are growing. I have been carried by the penetrating insight and forcible expression of Dr. Tyndall into that sanctuary of minuteness and of power where molecules obey the laws of their existence, clash together in fierce collision, o: grapple in yet more fierce embrace, building up in secret the forms of visible things. I have been guided by Professor Sylvester towards those serene heights

$$
\begin{aligned}
& \text { "Where never creeps a cloud, or moves a wind, } \\
& \text { Nor ever falls the least white star of snow, } \\
& \text { Nor ever lowest roll of thunder moans, } \\
& \text { Nor sound of human sorrow mounts, to mar } \\
& \text { Their sacred everlasting calm." }
\end{aligned}
$$

But who will lead me into that still more hidden and dimmer region where Thought weds Fact; where the mental operation of the mathematician and the physical action of the molecules are seen in their true relation? Does not the way to it pass through the very den of the metaphysician, strewed with the remains of former explorers, and abhorred by every man of science? It would indeed be a foolbardy adventure for me to take up the valuable time of the section by leading you into those speculations which require, as we know, thousands of years even to shape themselves intelligibly.

But we are met as cultivators of mathematics and physics. In our daily work we are led up to questions the same in kincl with those of metaphysics; and we approach them, not trusting to the native penetrating power of our own minds, but trained by a long-continued adjustment of our modes of thought to the facts of external nature. As mathematicians, we perform certain mental operations on the symbols of number or of quantity, and, by proceeding step by step from more simple to more complex operations, we are enabled to express the same thing in many different forms. The equivalence of these different forms, though a necessary consequence of self-evident axioms, is not always, to our minds, self-evident; but the mathematician, who, by long practice, has acquired a familiarity with many of these forms, and has become expert in the processes which lead from one to another, can often transform a perplexing expression into another which explains its rneaning in more intelligible language.

As students of physics, we observe lhenomena under varied circumstances, and endeavour to deduce the laws of their relations. Every natural phenomenon is, to our minds, the result of an infinitely complex system of conditions. What we set ourselves to do is to unravel these conditions, and by viewing the phenomenon in a way which is in itself partial and imperfect, to piece out its features one by one, beginning with that which strikes us first, and thus gradually learning how to look at the whole phemomenon so as to obtain a continually greater degree of clearness and distinctness. In this process, the feature which presents itself most forcibly to the untrained inquirer may not be that which is considered most fundamental by the experienced man of science; for the success of any physical investigation depends on the judicions selection of what is to be observed as of primary importance, combined with a voluntary abstraction of the mind from those features which, however attractive they appear, vre are not yet sufficiently advanced in science to investigate with profit.

Intellectual processes of this kind have been going on since the first formation of language, and are going on still. No doubt the feature which strikes us first and most forcibly in any phenomenon, is the pleasure or the pain which accompanies it, and the agreeable or disagreeable results which follow after it. A theory of nature from this point of view is embodied in many of our words and phrases, and is by no means extinct even in our deliberate opinions. It was a great step in science when men became convinced that, in order to understand the nature of things, they must begin by asking, not whether a thing is good or bad, noxious or beneficial, but of what kind is it? and how much is there of it? Quality and quantity were then first recognised as the primary features to be observed in scientific inquiry. As science has been developed, the domain of quantity has everywhere encroached on that of quality, till the process of scientific inquiry seems to have become simply the measurement and registration of quantities, combined with a mathematical discussion of the numbers thus obtained. It is this scientific method of direcing our attention to those features of phenomena which may be regarded as quantities which brings physical research under the influence of mathematical reasoning. In the work of the section we shall have abundant examples of the successful application of this method to the most recent conquests of science; but I wish at present to direct your attention to scme of the reciprocal effects of the progress of science on those elementary conceptions which are sometimes thought to be beyond the reach of change.

If the skill of the mathematician has enabled the experimentalist to see that the quantities which he has measured are connected by necessary relations, the discoveries of physics have revealed to the mathematician new forms of quantities which he could never have imagined for himself. Of the methods by which the mathematician may make his labours most useful to the student of nature, that which I think is at present most important is the systematic classification of quantities. The quantities which we study in mathematics and physics may be classified in two different ways. The student who wishes to master any particular science must make himself familiar with the various kinds of quantities which belong to that science. When he understands all the relations between these quantities, he regards them as forming a connected system, and he classes the whole system of quantities together as belonging 
to that particular science. This classification is the most natural from a physical point of view, and it is generally the first in order of time. But when the student has become acquainted with several different sciences, he finds that the mathematical processes and trains of reasoning in one science resemble those in another so much that lis lknowledge of the one science may be made a most useful heip in the study of the other. When he examines into the reason of this, he finds that in the two sciences lie has been dealing with systems of quantities, in which the mathematical forms of the relations of the quantities are the same in both systems, though the physical nature of the quantities may be utterly different. He is thus led to recognise a classification of quantities on a new principle, according to which the physical nature of the quantity is subordinated to its mathematical form. This is the point of view which is characteristic of the mathematician; but it stands second to the physical aspect in order of time, because the human mind, in order to conceive of different kinds of quantities, must have them presented to it by nature. I do not here refer to the fact that all quantities, as such, are subject to the rules of arithmetic and algebra, and are therefore capable of being submitted to those dry calculations which represent, to so many minds, their only idea of mathematics. The human mind is seldom satisfied, and is certainly never exercising its highest functions, when it is doing the work of a calculating machine. What the man of science, whether he be a mathematician or a physical inquirer, aims at is, to acquire and develop clear ideas of the things he deals with. For this purpose he is willing to enter on long calculations, and to be for a season a calculating machine, if he can only at last make his ideas clearer. But if he finds that clear ideas are not to be oltained by means of processes, the steps of which he is sure to forget bafore he has reacher the conclusion, it is much better that he should tum to another method, and try to understand the subject by means of well-chosen illustrations derived from subjects witł which be is more familiar. We all know how much more popular the illustrative method of exposition is found, than that in which bare proces:es of reasoning and calculation form the principal subject of discourse. Now a truly scientific illustration is a method to enable the mind to grasp some conception or law in one branch of science, by placing before it a conception or a law in a different branch of science, and directing the mind to lay hold of that mathematical form which is common to the corresponding ideas in the two sciences, leaving out of account for the present the difference between the physical nature of the real phenomena. The correctness of such an illustration depends on whether the two systems of ideas which are compared together are really analogous in form, or whether, in other words, the corresponding physical quantities really belong to the same mathematical class. When this condition is fulfilled, the illustration is not only convenient for teaching science in a pleasant and easy manner, but the recognition of the mathematical analogy between the two systems of ideas leads to a knowledge of both, more profound than could be obtained by studying each system separately.

There are mell who, when any relation or law, however complex, is put before them in a symbolical form, can grasp its full meaning as a relation among abstract quantities. Such men sometines treat with indifference the further statement that quantities actually exist in nature which fulfil this relation. The mental image of the concrete reality seems rather to disturb than to assist their contemplations. But the great majority of mankind are utterly unable, without long training, to retain in their minds the unembodied symbols of the pure mathematician; so that if science is ever to become popular and yet remain scientific, it must be by a profound study and a copious application of those principles of truly scientific illustration which, as we have seen, depend on the mathematical classification of quantities. There are, as I have said, some minds which can go on contemplating with satisfaction pure quantities presented to the eye by symbols, and to the mind in a form which none but mathematicians can conceive. There are others who feel more enjoyment in following geometrical forms, which they draw on paper, or build up in the empty space before them. Others, again, are not content unless they can project their whole physical energies into the scene which they conjure up. They learn at what a rate the planets rush through space, and they experience a delightful feeling of exhilaration. They calculate the forces with which the heavenly bodies pull at one another, and they feel their own muscles straining with the effort.

To such men impetus, energy, mass, are not mere abstract expressions of the results of scientific inquiry. They are words of power which stir their souls like the memories of childhood. For the sake of persons of these different types, scientific truths should be presented in different forms, and should be regarded as equally scientific, whether it appears in the robust form and the vivid colouring of a physical illustration, or in the tenuity and paleness of a symbolical expression. Time would fail me if I were to attempt to illustrate by examples the scientific value of the classification of quantities. I shail only mention the name of that important class of magnitudes having direction in space which Hamilton has called Vectors, and which form the subject-matter of the Calculus of Quaternions-a branch of mathematics which, when it shall have been thoroughly understood by men of the illustrative type, and clothed by them with physical imagery, will become, perhaps under some new name, a most powerful method of communicating truly scientific knowledge to persons apparently devoid of the calculating spirit. The mutual action and reaction between the different departments of human thought is so interesting to the student of scientific progress, that, at the risk of still further encroaching on the valuable time of the Section, I shall say a few words on a branch of science which not very long ago would have been considered rather a branch of metaphysics : I mean the atomic theory, or, as it is now called, the molecular theory of the constitution of bodies. Not many years ago, if we had been asked in what regions of physical science the advance of discovery was least apparent, we should have pointed to the hopelessly distant fixed stars on the one hand, and to the inscrutable delicacy of the texture of material bodies on the other. Indeed, if we are to regard Comte as in any degree representing the scientific opinion of his time, the research into what takes place beyond our own solar system seemed then to be exceedingly unpromising, if not altogether illusory. The opinion that the bodies which we see and handle, which we can set in motion or leave at rest, which we can break in pieces and destroy, are composed of smaller bodies which we cannot see or handle, which are always in motion, and which can neither be stopped nor broken in pieces, nor in any way destroyed or deprived of the least of their properties, was known by the name of the Atomic Theory. It was associated with the names of Democritus and Lucretius, and was commonly supposed to admit the existence only of atoms and void, to the exclusion of any other basis of things from the universe.

In many physical reasonings and mathematical calculations we are accustomed to argue as if such substances as air, water, or metal, which appear to our senses uniform and continuous, were strictly and mathematically uniform and continuous. We know that we can divide a pint of water into many millions of portions, each of which is as fully endawed with all the properties of water as the whole pint was, and it seems only natural to conclude that we might go on subdividing the water for ever, just as we can never come to a limit in subdividing the space in which it is contained. We have heard how Faraday divided a grain of gold into an inconceivable number of separate particles, and we may see Dr. Tyndall pruduce from a mere suspicion of nitrite of butyle an immense cloud, the minute visible portion of which is still cloud, and therefore must contain many molecules of nitrite of butyle. But evidence from different and independent sources is now crowding in upon us which compels us to admit that if we could push the process of subdivision still further we should come to a limit, because each portion would then contain only one molecule, an individual body, one and indivisible, unalterable by any power in nature. Even in our ordinary experiments on very finely divided matter we find that the substance is beginning to lose the properties whicl it exhibits when in a large mass, and that effects depending on the individual action of molecules are beginning to become prominent. The study of these phenomena is at present the path which leads to the development of molecular science. That superficial tenion of liçuids which is called capillary attraction is one of these the nomona. Another important class of phenomena are those which are due to that motion of agitation by which the molecules of a liquid or gas are continually working their way from one place to another, and continually changing their course, like people hustled in a crowd. On this depends the rate of diffusion of gases and liquids through each other, to the study of which, as one of the keys of molecular science, that unwearied inquirer into nature's secrets,' the late Prof. Graham, devoted such arduous labour.

The rate of electrolytic conduction is, according to Wiede. mann's theory, infuenced by the same cause ; and the conduction of heat in fluids depends probably on the same kind of action. 
In the case of gases, a molecular theory has been developed by Clausius and others, capable of mathematical treatment, and subjected to experimental investigation; and by this theory nearly every known mechanical property of gases has been explained on dynamical principles, so that the properties of individual gaseous molecules are in the fair way to become objects of sciuntific research. Now Sir William Thomson has sliown by several independent lines of argument, cirawn from phenomena so different in themselves as the electrification of metals by contact, the tension of soap-bubbles, and the friction of air, that in ordinary solids and liquids the average distance between contiguous molecules is less than the hundred-millionth, and greater than the two-thousand-millionth of a centimetre. This of course is an exceedingly rough estimate, for it is derived from measurements, some of which are still confessedly very rough; but if, at the present time, we can form even a rongh plan for arriving at a result of this kind, we may hope that as our means of experimental inquiry become mure accurate and more varied, our conception of a molecule will become more definite, so that we may be able at no distant period to estimate its weight. A thenry which Sir W. Thomson has founded on Helmholtz's splendid hychrodynamical theurems, seeks for the properties of molecules in the ring-vortices of a uniform, frictionless, incompressible flitid. Such whirling rings may be seen whith an experienced smoker sends out a dexterous puff of smoke into the stili air, but a more evanescent phenomenon it is difficult to conceive. Thi evanescence is owing to the viscosity of the air ; but Helmluvit. has shown that in a perfect fluid such a whinling ring, if once grenerated, would go on whirling for ever, woukl always consist of the very same portion of the fluid which was first set whining, and could never be cut in two by any natural canse. The gene. ration of a ring-vortex is of course equally beyond the puwer of natural causes, but once generated, it has the properties of individuality, permanence in quantity, and indestructibility. I is also the recipient of impulse and of energy, witich is all wo can affrm of maiter: and theje ring-vortices are capable of such varied connections, and knotted self-involutions, that the properties of differently knotted vortices must be as different as those of different kinds of molecules can be.

If a theory of this kind should be found, after conquering the enormous mathematical clificulties of the subject, to represent in any deyree the actual properties of molecules, it wili stand in a very different scientific josition from those theories of molecular action which are formed by investing the molecule with an arbitrary system of central forces invented expressly to account for the observed phenomena. In the vorlex theory we have mothing arbitrary, no central forces or occtilt properties of any other kind. We have nothing but matter and motion, and when the vortex is once started its properties are all determined from the original impetus, and no further assumptions are possible. Even in the present undeveloped state of the theory, the contemplation of the individuaiity and indestructibility of a ring vortex in a perfect fluid cannot fail to disturb the commonly received opinion that a molecule, in order to be permanent, must be a very hard body. In fact one of the first conditions which a molecule must fuifil is, apparently, inconsistent with its being a single hard body. We know from those spectroscopic researches which have thruwn so much light on different branches of science, that a molecule can be set into a state of internal vibration, in which it gives off to the surrounding medium light of definite refrangibility-light, that is, of definite wave-length and definite period of vibration. 'The fact that all the molecules, say of hydrogen, which we can procure for our experiments, when agitated by heat or by the passage of an electric spark, vibrate precisely in the same periodic time, or, to speak more accurately, precisely vibrations are composed of a system of simple vibrations having always the same periods, is a very remarkable fact. I must leave it to others to describe the prosiress of that splen lid series of spectroscopic discoveries by which the chemistry of the heavenly bodies has been brought within the range of huinan inquiry. I wish rather to clirect your attention to the fact that quiry. system of periods of free vibration, but that the spectroscope examination of the light of the sun and stars shows that in regions the cistance of which we can only feebly inagine there are molecules vibrating in as exact unison with the molecules of terrestrial hydrogen as two tining forks tuned to correct pitch, or tiro watches regulated to solir time. Now this absolute equality in the masnitude of quantities, occurring in all parts of the universe, is wortl our consideration. The dimensions of individual natiral bodies are either quite indeterminate, as in the case of planets, stones, trees, \&c., or they vary within moderate limit, as in the case of seeds, eggs, \&c.; but, even in these cases, small quantitive clifferences are met with which do not interfere with the essential properties of the body. Even crystals, which are so definite in geometrical form, are variable with respect to their absolute dimensions. Among the works of man we sometimes find a certain degree of uniformity. There is a uniformity among the different bullets which are cast in the same mould, and the different copies of a book printed from the same type. If we examine the cuins, or the weights and measures, of a civilised country, we find a uniformity, which is produced by careful adjustment to standards made and provided by the State. The degree of uniformity of these national standards is a measure of that spirit of justice in the nation which has enacted laws to regulate them and appointed officers to test them. 'linis subject is one in which we, as a scientific body, iuke a warm interest, and you are all aware of the vast amount of scientific work which has been expended, and profitably expended, in providing weights and measures for commercial and scientific purposes. The earth has been measured as a basis for a permanent standard of length, and every property of metals has been investigated to guard against any alteration of the material standards when made. To weigh or measure anything with modern accuracy, requires a course of experiment and calculation in which almost every branch of physics and mathematics is brought into requisition.

Yet, after all, the dimensions of our earth and its time of rotation, thcugh, relatively to our present means of comparison, very permanent, are not so by any physical necessity. The earth minht contract by cooling, or it might be enlarged by a layer of meteorites faling on it, or its rate of revolution might slowly slacken, and yet it would continue to be as much a planet as before. But a molecule, say of hydrogen, if either its mass or its time of vibration were to be altered in the least, would no iunger be a molecule of hydrigen. If, then, we wish to obtain stanclards of length, time, and mass which shall be absolutely permanent, we must seek them not in the dimensions, or the inotion, or the mass of our planet, but in the wave-length, the period of vibration, and the absolute mass of these imperishable and unalterable and periectly similar molecules. When we find that here, and in the starry heavens, there are innumerable multitudes of little bodlies of exactly the same mass, so many, and no more, to the grain, and vibrating in exactly the same time, so many times, and no more, in a second, and when we reflect that no power in nature can now alter in the least either the mass or the period of any one of them, we seem to have advanced along the path of natural knowledge to one of those points at which we must accept the guidance of that faith by which we understand that "that which is seen was not made of things which do appear." One of the most remarkable results of the progress of molectlar science is the light it has thrown un the nature of irreversible processes, - processes, that is, which always tend towarls, and never away from, a certain limiting state. Thus if two gases be put into the same ve sel they become mixed, and the mixture tends continually to become more uniform. If two unequally heated portions of the same gas are put into the vessel, something of the kind takes place, and the whole rends to become of the same temperature. If two unequaly heated solid bodies be placed in contact, a continual ajproximation of both to an intermediate temperature takes place. In the case of the two gases, a separation may be effected by chemical means; but in the other two cases the former state of things cannot be restored by any natural process. In the case of the conduction or diffusion of heat the process is not only irreversible, but it involves the irreversible diminution of that part of the whole stock of thermal enery which is capable of being converted into mechanical work. This is Thomson's theory of the irreversible dissipation of energy, and it is egrivillent to the doctrine of Clausius concemin the growth of what he calls Entropy. The irreversibie character of this process is strikingly enbodied in Fourier's theory of the conduction of heat, where the formula themselves indicate a possible solution. of all positive values of the time which continually tends to a tuniform diffusion of heat. But : we attempt to ascend the stream of time by giving to its symbcl continually diminishing values, we are led up to a state of things in which the formula has what is calle: a critical value; and if we inquire into the state of things the instant before, we find thet the formula becones ahsurd. We thus arrive at the conception of a state of thinigs which cannot be conceived as the physical 
result of a previous state of things, and we find that this result of a previous condition actually existed at an epoch not in the ntmost depths of a past eternity, but separated from the present time by a finite interval. This idea of a beginning is one wlich the physical researches of recent times have brought home to us, more than any observer of the course of scientific thought in former times would have had reason to expect. But the mind of man is not like Fourier's heated body, continually settiing down into an ultimate state of quiet uniformity, the character of which we can already predict; it is rather like a tree shooting out branches which adapt themselves to the new aspects of the sky towards which they climb, and roots which contort themselves among the strange strata of the earth into which they delve. To us who breathe only the spirit of our own age, and know only the characteristics of contemporary thought, it is as impossible to predict the general tone of the science of it is as impossible to participate the particular discoveries which it will make. Physical research is continually revealing to us new features of natural processes, and we are thus compelled to search for new forms of thought appropriate to these features. Hence the importance of a careful study of those relations between mathematics and physics which determine the conditions under which the ideas derived from one department of physics may be safely used in forming ideas to be employed in a new department. The figure of speech or of thought by which we transfer the language and ideas of a familiar science to one with which we are less acquainted may be called scientific metaphor. Thus the worảs velocity, momentum, force, \&c., have acquired certain precise meanings in elementary dynamics. They are also employed in the dynamics of a connected system in a sense which, though perfectly analogous to the elementary sense, is wider and though perfectly analogous to the elementary sense, is wideas may be called metaphorical terms in the sense in which every abstract term is metaphorical. The characteristic of a truly scientific system of metaphors is that each term in its metaphorical use retains all the formal relations to the other terms of the system which it had in its original use. 'The method is then truly scientific, that is, not only a legitimate product of science, but capable of generating science in its turn. There are certain electrical phrnomena, again, which are connected together by relations of the same form as those which connect dynamical phenomena. To apply to these the phrases of dynamics with proper distinctions and provisional reservations is an example of a metaphor of a bolder kind; but it is a legitimate metaphor if it conveys a true idea of the electrical relations to those who have betn already trained in dynamics. Suppose, then, that we have successfully introduced certain ideas belonging to an elementary science by applying them metaphorically to some new class of phenomena. It becomes an important philosophical question to determine in what degree the applicability of the old ideas to the new subject may be taken as evidence that the new phenomena are physically similar to the old. The best instances for the determination of this question are those in which two different explanations have been given of the same thing. The most celebrated case of this kind is that of the corpuscular and the undulatory theories of light. $U_{p}$ to a certain poirst the phenomena of light are equally well explained by both; beyond this point one of them fails. To understand the true relation of these theories in that part of the field where they seem equally applicable we must look at them in the light which Hamilton has thrown upon them by his discovery that to every brachystochrone problem there corresponds a problem of free motion, involving different velocities and times, but resulting in the same geometrical path. Professor Tait has written a very interesting paper on this subject. According to a theory of electricity which is making great progress in Gernany two electrical particles act on one another directly at a distance, but with a force which, according to Weber, depends on their relative velocity, and according to a theory hinted at by Gauss, and developed by Riemann, Lorenz, and Neumann, acts not instantaneously, but after a time depending on the distance. The power with which this theory, in the hands of these eminent men, explains every kind of electrical phenomena must be studied in o:der to be appreciated. Another theory of electricity which I prefer denies action at a distance and attributes electric action to tensions and pressures in an all-pervading medium, the e stresses being the same in kind with those familiar to engineers, and the medium being identical with that in which ligut is supposed to be propagated. Both these theories are found to explain not only the phenomena by the aid of which they were originally constructed, but other phenomena which were not thought of, or perhaps not known at the time, and both have independently arrived at the same numerical result which gives the absolute velocity of light in terms of electrical quantities. That theories, apparently so fundamentally opposed, should have so large a field of truth common to both is a fact the philosophical importance of which we cannot fully appreciate till we have reached a scientific altitude from which the true relation between hypotheses so different can be seen.

I shall only make one more remark on the relation between mathematics and physics. In themselves, one is an operation of the mind, the other is a dance of molecules. The molecules have laws of their own, some of which we select as most intelligible to us and most amenable to our calculation. We form a theory from these partial data, and we ascribe any deviation of the actual phenomena from this theory to disturbing causes. At the same time, we confess that what we call disturbing causes are simply those parts of the true circumstances which we do not know or have neglected, and we endeavour in future to take. account of them. We thus acknowledge that the so-called disturbance is a mere figment of the mind, not a fact of nature, and that in natural action there is no disturbance. But this is not the only way in which the harmony of the material with the mental operation may be disturbed. The mind of the mathematician is subject to many disturbing causes, such as fatigue, loss of memory, and hasty conclusions; and it is found that from these and other causes mathematicians make mistakes. I am not prepared to deny that, to some mind of a higher order than ours, each of these errors might be traced to the regular operation of the lawrs of actual thinking; in fact we ourselves olten do detect, not only errors of calculation, but the causes of these errors. 'This, however, by no means alters our conviction that they are errors, and that one process of thought is right and another process wrong. One of the most profound mathe maticians and thinkers of our time, the late George Boole, when reflecting on the precise and almost mathematical character of the laws of right thinking as compared with the exceedingly perplexing, though perhaps equally determinate, laws of actual and fallible thinking, was led to another of those points of view from which science seems to look out into a region beyond her own domain. "We must admit," he says, "that there exist laws " (of thought) "which even the rigour of their mathematical forms does not preserve from violation. We must ascribe to them an authority, the essence of which does not consist in power, a supremacy which the analogy of the inviolable order of the natural world in no way assists us to comprehend."

Section B.-Chemical Science.-President, Professor Roscue, F.R.S.

Report of the Conmittee on the Chemical Nature of Cast Iron. - Mr. David Forbes, F.R.S., reported on behalf of Professor Abel, Dr. Matthiessen and himself, that it had not been in their power, as a Committee, to make any important progress in the investigation of the chemical nature of cast iron during the past year. This was partly owing to the dismantled condition of the required apparatus. The Committee asked to be reappointed, so that the experiments might be resumed without much further delay.

On a New Chlorine Process without Manganese.-Mr. Henry Deacon, of Widnes. As the closing paragraph of Professor Roscoe's address briefly and clearly described the essential nature of Mr. Deacon's process, it is not necessary further to refer to it, except to state that hitherto Mr. Deacon has not succeeded in making the process a commercial success, and he prefers in the meantime to employ Mr. Weldon's process, though he is satisfied that his own will yet become practically applicable in the production of chlorine for the manufacture of bleaching powder.

SeCtron C.-Geology.-President, Sir Philip de Malpas Grey Egerton, Bart., M.P., F.R.S.

The President departed from the practice of giving an introductory address, inasmuch as the time of the Section would be fully occupied with the reading and discussion of the papers to be submitted to it.

On the Glaciated Surface of Triassic Rocks near Liverpool. Mr. G. H. Morton. The grooves on the rocks were of a uniform direction, $35^{\circ} \mathrm{W}$. of $\mathrm{N}$, and were due to the action of land ice. 
Mr. Boyd Dawkins and Rev. Mr. Crosskey distinguished between the deposits produced by land ice and the later deposits containing stones dropped from floating ice. Professor Hawkins insisted that the granite boulders of Lancashire and Cheshire were derived from Ravenglass and not from Shapfell as stated; but Professor Williamson and Mr. Dawkins asserted that they had found Shap boulders in the clay.

On Sections of Strata between Huyton and St. Helens, exposed in cuttings in the railway now making between these places. -Dr. Ricket ts

R'eport on Slicing and Photographing of Fossil Corals.-Mr. James Thompson. The continued investigation of these fossils had added greatly to the number of species, and the prepared sections had exhibited indications which supplied characters by which recognised forms could be better distinguished and false species eliminated. The report was accompanied with a large series of slices and exquisite photographs, full of promise for the future students of the group.

Report on the Fossils of Kiltorcan.-Mr. W. H. Balley. These consisted of specimens of Cyclopteris hibernica, the remains of Sagenaria bayleana, a freshwater shell, Anodonta jukesii a crustacean Protocaris mehertici, and scales of Coccosteus and Gisptolepis. Mr. R. H. Scott stated that Professor Heer had determined the specific identity of fossils from Bear Island collected by the Swedish Polar expedition in 1869 , with those from Kiltorcan. Mr. Carruthers had recently examined the extensive series of Kiltorcan Fossils at Dublin, made by Mr. Bailey. They supplied information regarding all the parts of the Sagenaria and Cyclopteris, enabling investigators to deal with them almost as satisfactorily as with recent plants.

Fourth Report on the Leaf-beds of the Bayshot Series of Hantpshire.-Mr. W. S. Mitchell.

On the Evidences of Recent Chunges of Level on the Mecititer runean Coast.--Mr. G. Maw. The coast structure, the general absence of sea-cliffs within the straits of Gibraltar, due to the shelving of the contour of the land under the sea were described. The inset current from the Atlantic was considered as indicating a general subsidence of the whole Mediterranean basin. The submarine springs passing through channels of sub-aerial origin occurring in the coast caverns implied a submergence of the const line. Evidences of upheaval were to be found in the lagoons and flats which abound on the coast of Corsica, and which are covered with long ridges of shingle deposited, it was believed, by streams which debouthed on the marsh when it was submerged. Further at Gibraltar a great deposit of stratified sand in Catalan Bay, showing a submergence of 700 feet; and at Cadiz, as well as a Tangiers on the opposite side of the basin, raised sea beaches were found. Sir Charles Lyell thought the out-set curren balanced the inset one and destroyed the value of that current as supporting the notion of submergence. Prof. Busk referred to the memoirs of the late Mr. Smith, of Jordanhill, on the Mediterranean basin, and at length gave his own observations on the rock terraces and caverns of the rock of Gibraltar. There were three successive terraces exhibited only on the eastern side of the rock, showing that a barrier extended in recent geological times across the straits confining the Mediterranean to a higher level than the Atlantic. The changes described by Mr. Maw were really the last of a series indicated by the terraces at Gibraltar. Prof. Ansted thought the great power of enormously swollen streams so common in Corsica and neighbouring regions might account for some of the phenomena referred to by the author.

On the Organisation and Affinities of the Calamites of the Coal Measures.--Prof. Williamson. Numerous well preserved and novel forms of stems of Calamites were described with great minuteness, and estimates of their systematic position, based on these structures, were suggested. The author described two forms of nodullary rays, and a third set of radiating cellular structure connected with nodes. He considered the phragmas seen on Calamite stems to indicate the attachment of the roots. He suggested that this group of fossils must be separated from the Equisetacee and placed in an order to which he proposed to join the name Calamitacea. Mr. Cann thus doubted whether systematic determinations based on stem structure were of value. $\mathrm{He}$ preferred the evidence derived from the fruit, and that had been determined to differ very little from the fruit of the living Equisetzm. The various points of difference pointed out by the author he considered to depend upon the more highly organised vegetative portions of the fossils, and exogenons growth of the stems. Mr. Bentham insisted on the value of fruit characters for determining systematic position, and urged the desirability of employing subgeneric names for imperfectly determined forms.

Section D.-Biological Science-President, Prof. Rolleston, M.D., F.R.S.

The President delivered the following address :-

Amongst the duties of the President of a Section the delivery of an Address has in these latter days somehow come to be reckoned, and that I may interpose myself for but as short a time as possible between your attention and the papers announced to you for reading upon your list, I will begin what I have to say without any further preface.

I wish first to make a few observations as to the kind of preparation which is indispensable, as it seems to me as a preliminary to an adequate and intelligent comprehension of the problems of biology ; or, in other words, to an adequate and intelligent comprehension of the discussions which will take place in this room and in the two other rooms which will be assigned to, and occupied by, the departments of Ethnology and Anthropology, and that of Physiology Pure and Proper, and Anatomy.

Having made these observations, I propose, in the second place, to enumerate the subjects which appear likely to occupy prominent places in our forthcoming discussions; and thirdly, I will, if your patience allows me, conclude with some remarks as to certain of the henefits which may be expected, as having been constantly observed to flow from a due and full devotion to biological study.

In the first place, then, I wish to say that though the problems of biology have much of what is called general interest; that is to say, of intere.t for all persons, attaching to them, as indeed how could they fail to have, including as they do the natural history of our own and of all other species of living organisms, whether animal or vegetable; some special preparation must be gone through if that general interest is to be thoroughly and intelligently gratified. I would compare the realm of biology to a vast landscape in a cultivated country of which extensive views may be obtained from an eminence; but for the full and thorough appreciation of which, if necessary, the gazer should himself have cuitivated some portion, however small, of the expanse at his feet. It is, of course, a matter of regret to think that persons can be found who look upon an actual landscape without any thought or knowledge as to how the various factors which make up its complex beauty have come to co operate; how the hand of man is recognisable here; how the dip of the strata is visible there; and how this alternation is detectable in another place as the potent agency in giving its distinctive features; but $I$ take it that real and permanent, however imperfect, pleasure may be drawn from the contemplation of scenery by persons who are ignorant of all these things. I do not think this is the case when we here deal with coup d"xil views of biology. The amount of the special knowledge, the extent of the special training need not necessarily be great, but some such special knowledge and training there must be if the problems and argumentations familiar to the professed biologist are to be understood and grasped by persons whose whole lives are not devoted to the subject, so as to form for them acquisitions of real and vital knowledge.

The microscope has done very much, indeed I may say it has done almost all that is necessary for enabling all persons to obtain the necessary minimum of practical and personal acquaintance with the arrangements of the natural world of which $I$ am speaking. The Glass trough used in Edinburgh, the invention of John Goodsir, whose genius showed itself, as genius often does show itself, in simple inventions, can be made into a miniature aquarium. I' purposely use a word which calls up the idea of an indoors apparatus, wishing thereby to show how the means I recommend are within the reach of all persons; and in it, lying as it does horizontally and underlaid as it is by a condenser, animal and vegetable organisms can be observed at any and at all hours, and continuously, and with tolerably high magnifying povers even whilst undisturbed. Thus is gained an admirable field for the self-discipline in question. The microscope which should be used by preference for exploring and watching such an aquarium should be such an one as is figured in Gaskell's work on the Microscope (p. 58, fig. 36), as consisting of a stem with a stout steadying base, and of a horizontal arm some nine inches long, which can carry indifferently simple lenses or a compound body. I think of the two it is better that the aquarium should be horizontal rather than the microscope; and those who think with me 
in this matter can nevertheless combine for themselves the advantages of the horizontal position of the instrument with those of the horizontal position of the objects observed by modifying the eye-piece in the way figured by Quekett (p. 38I, fig. 266.) It would be a long task to enumerate fully all the scientific lessons which may be gathered, firstly, and all the educational agencies, secondly, which may be set and kept in movement by a person who possesses himself of this simple apparatus. The mutual interdependence of the animal and vegetable kingdoms, their solidarité as the French have called it, and as the Germans have called it too, copying herein the French, is one of the first lessons the observer has forced upon him ; the influence of physical and chemical agencies upon the growth and development of living beings he soon finds strikingly illustrated ; the mysterious process of development itself is readily observable in the eggs of the common water-snails and in those of freshwater fish, so that the way in which the various organs and systems of organs are chiselled out, built up, and finally packed together and stratified can be taken note of in these yet transparent representatives of these great sub-kingdons which all the while are undisturhed and at peace; and all these points of large interest are but a few of many which these small means will enable anyone to naster for himself in the concrete actuality, and thoroughly. The necessity for carefulness and truthfulness in recording what is seen, the necessity for keeping in such records what one observes quite distinct from what one infers, the necessity for patience and punctuality, are lessons which, from having a moral factor as well as a scientific one in their composition, I may specify as belonging to the educational lessons which may be gathered from such a course of study.

I have been speaking of the microscope as an instrument of education, and I wish before leaving the subject to ntter one cantion as to its use when this particular object of education is in vicw. If a subject is to act educationally, it must be understood thoroughly; and if a subject is to be understood thoroughly, it must form one segment or stretch in a continuous chain of known

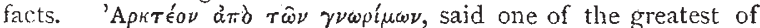
educators; you must start from some previously existing basis of knowledge, and keep your communications with it uninterrupted if your knowledge is not to be unreal. And my concrete application of these generalities is contained in the advice that no sudden jump be made from observations carried on with the naked eye to observations carried on with the highest powers of the microscope. I am speaking of the course to be pursued by beginners, and beginners we all were once, and if our places are to be filled, and filled they will be, by better men as we hope than ourselves, they will have to be filled, we also hope, by men who have yet to become beginners. It is in their interest $I$ have been speaking, and I say that a beginner does not ordinarily sret an intelligent conception of the revelations of the microscope txcept in Bacon's words, Ascendendo continenter et graulatium, by progressing gradually from observations with the naked eye through observations dependent upon dissecting lenses, doublets and triplets, and the lower powers of the compound microscope, up to observations to be made with the higher and highest magnifying powers.

Unless he ascend by gradations from organs and systems; structures and tissues and cells, his wonder and admiration at the results of the ultimate microscope analysis, of what he had but a moment before knowledge of only in the concrete and by the naked eye is likely to be but unintelligent.

There a:e three other agencies which can be set into activity with nearly as little trouble and difficulty as the simple apparatus of which I have just been speaking, and which will, like it, secure as a necessary preliminary discipline "propädeutik" for their rational comprehension of Biology. These are Local Museums, Incal Field Clubs, and Local Natural Histories. Local authorities, persons of local influence, should engage and interest themselves in the starting into life of the two former of these agencies, and if some such person as Gilbert White could be found in each county to write the Natural History of its Selhorne, I know not at what cost it could not be well to retain his services. As the world is governed upon each particular area of its surface, there is to be found a certain percentage of the population occupying it who have special calls for particular lines of study. It is the interest of each county to have such means and such institutions in being as will render it possible to detect the existence of persons gifter with such special vocations, to give the talent thus entrusted to them fair scope for developinent, and to render smaller the risk of their dying mute and in- glorious. A young man who is possessed of a talent for Natural Science and Physical Inquiry generally, may have the knowledge of this predisposition made known to himself and to others, for the first time, by his introduction to a well-arranged Loca Museum. In such an institution, either all at once, or gradnally, the conviction may spring up within him that this investigation of physical emblems is the line of investigations to which he should be content to devote himself, relinquishing the pursuit of other things; and then, if the museum in question is really a well-arranged one, a recruit may be thereby won for the first and growing army of physical investigators, and one more man saved from the misery of finding, when he has been taken into some other career, that he has somehow or other mistaken his profession, and made of his career one life-long mistake. Here comes the question. What is a well-arranged museum? The answer is, a well-arranged museum for the particular purpose of which we are speaking, is one in which the natural objects which belong to the locality, and which have already struck upon the eye of such a person as the one contemplated, are clearly explained in a well-arranged catalogue. The curiosity which is the mother of science is not awakened for the first time in the museum, but ont of doors, in the wrood, by the side of the brook, on the hillside, by scarped cliff and quarried stone; it is the function of the museum, by rendering possible the intellectual pleasure, which grows out of the surprise with which a novice first notes the working of his faculty of inspiration, to prevent this curiosity from degenerating into the mere wood: man's craft of the gamekeeper, or the rough empiricism of the farmer. The first step to be taken in a course of natural instruction, is the providing of means whereby the faculties of observation and of verification may be called into activity; and the first exercise the student should be set down to is that of recognising in the actual thing itself, the various properties and peculiarities which some good book or some good catalogue tells him are observable in it. This is the first step, and, as in some other matters, ce n'est que le premier pas qui coute. And it need not cost much. There is a name familiar to Section $D$, and indeed not likely for a long whi'e to be forgotten by members of the British Association generally, extrinsic means as well as the intrinsic merits of the well-loved man conspiring to keep his memory fresh among us, and the bearer of that name, Edward Forbes, has left it as his opinion that "It is to the development of the provincial museums that, I believe, we must look in future for the extension of intellectual pursuits thronghout the land." (Lecture "On the Educational Uses of Museums," delivered at the Museum of Practical Geology and published in 1853 . Cited by Toynbee, "Hints on the Formation of Local Museums," 1863 , p. 46.) With the words of Edward Forbes I might do well to end what I have to say, but I should like to say a word as to the policy of confining the contents of a local museum to the naturalbistory-specimens of the particular locality. No cloubt the frst thing to be done is the collection of the local sfecimens, and this alike in the interest of the potential Cuviers and Hugh Millers, who may be born in the district, and in the interest of the man of science who may visit the place when on his travels. But so long as a specimen from the antipoctes or from whatever comer of our world be really valuable, and be duly catalogued before it is admitted into the museum; so that the lesson it has to teach may be learnable, I do not see my way towards advising that foreign specimens be excluded. It is to my mind more important that all specimens should be catalogued as soon as received, than that any should be rejected when offered.

I must not occupy your time further with this portion of my address. Let me first say that a person who wishes to know what a Field Club can do for its members, and not for them only, but for the worlct at large, will do well to purchase one, or any number more than one, of the Transactions of the Tyneside Nattralist's Field Club; and that if there be any person who thinks that White's Selborne relates to a time and place so far off that there can be no truth in the book, and who yet would like to try upon himself the working of the fourth disciplinary agencies of which I have spoken; that, namely, of sending some Local Natural History on the spot of which it treats; and comparing it with the things themselves in situ, let him repair to Weymouth, and work and walk up and down its cliffs and valleys with Mr. Darwin's book in his hands.

I shall not be suspected in this place and upon this occasion, nor, as I hope, upon any other, of a wish to depreciate the value of scientific instruction as an engine for training the mind. But neither, on the other hand, should I wish to depreciate the value 
of litentry culture, ny ver of the relations of these two gynnastics of the mind being the very simple, obvious, and natural one that they should be harmoniously combined-

\section{Altera ṣ̀̀ poscit opem vis, et conjuviat amice.}

I know it may be said that there are difficulties in the way, and especialiy practical difficulties, but I have always observed that preple whu are good at finding out difficulties, and especially practical difficulties, are like people who are good at finding out cxcuses,--good at finding out very little else. The various ways of getting over these difficulties are obvious enough, and have been hinted at, or fully expressed by several writers of greater or less authority on many occasions. It is, however, of some consequence that I should here say what I believe has not been said before, namely, that a purely and exclusively literary education imperfect and one sided, as it is, is still a better thing than a system of scientific instruction (to abuse the use of the word for a moment) in which there should be no courses of practical familiarising with natural objects, verification, and experimentation. A purely literary training, say, in dialectics, or what we are pleased to call logic, to take a flagrant and glaring instance first, does confer certain lower advantages upon the person who goes through it without any discipline in the practical investigation of actual problems. By going through such a training attentively, a man with a good memory and a little freedom from over-scrupulousness, can convert his mind into an arsenal of quips, quirks, retorts, and epigrams, out of which he can, at his own pleasture, discharge a mitraille of chopped straw and chaff-like arguments, against which no man of ordinary fairness of mind can, for the moment, make head. It is true that such sophists gain this dexterity at the cost of losing, in every case, the power of fairly and fully appreciating or investigating truth; of losing in many cases the faculty of sustaining and maintaining serious attention to any subject; and of losing in some cases cven the power of writing. A well-known character in an age lappily, though only recently, gone by, who may be taken as a Cxar workhy of such Antonies, used to speak of a pen as his torpedo. Scill they have their reward, they succeed now and then in convincing juries, and they are formidable at dinner tables. It would not be fair, however, not to say that a purely 1 terary training can do much better things than this. By a purely Classical Education a man, from being forced into seeing and feeling that other men could look upon the world, moral, sxial and physical, with other (even if not with larger) eyes than ous, aitains a certain flexibility of mind which enables him $t$, enter into the thoughts of other and living men, and this is a vary desirable attainment. And, fnally, though I should be s sry to hold with a French writer that the style makes the man, the benefit of being early familiariste with writings which the peculiar social condition of the classical times, so well pointed out by De Tocqueville (De la Démocratie en Amúrique), conspired and contributed not a little to make models of style, is not to be despised. Such a familiarity may not confer the power of imitating or rivalling such compositions, but it may confer the power of appreciating their excellences, the one power appearing to us to be analogous tu the power of the experimenter, and the other to that of the pure olserver in Natural Science; and we should undervalue neither.

Masters of Science, it must be confessed, are not always masters of style; let not the single instance of last night tempt you. to generalise, it was but a single instance, the writings of the man whum we in this Section are most of us likely to look iivon as our master in Science have been spoken of by our l'resident in his recently published volume as "intellectual pemmican;" and if scientific reading and teaching is to be divorced from scientific observation of natural objects and processes, it is better that a man, young or old, should have in his memory something which is perfect of its kind, entire and unmutilated, such as the opening of sentences of the Brutus of Cicero, which Tacitus, I think, must have had in his memory when he wrote his obituary of Agricola, or as the opening sentences of the Republic of Flato, or the conclusion of the Ajax or Sophocles, than that he should have his memory laden with a consignment of scientific phrases which ex hypothesi have for him no virtual reality. I have already said that I am strongly of opinion that literary should always be combined with scientific instruction in a perfect educational course; these somewhat lengthy remarks refer therefore only to systems in which it is proposed that we should have not only a bifurcation but a radical separation of studies and students, and the moral of this may be summed up by saying that a purely scientific education must be a thoroughly practical one, familiarising the student with actual things as well as with words and symbols. It was upon the solid ground that Antæus learnt the art of wrestling, it was only when he allowed himself to be lifted from it that he was strangled by Hercules.

Coming now to the second part of my address, I beg to say that the word Biology is at present used in two senses, one wider, the other more restricted. In this latter sense the word bccomes equivalent to the older, and till recently more currently used word "Physiology;" it is in the vider sense that the word is used when we speak of this as being the section of biology; and this willer sense is a very wide one, for it comprehends anmal and vegetable Physiology and Anatomy, firstly ; Lihmology and Anthropology, secondly; and thirdly, Scientific Zoology and Classificatory Botany, inclusively of the Distribution of Species. It may have been possible in former times for a single individual of great powers of assimilation to keep limuself abreast of, and on a level with, the advance of knowledge along all these varions lines of investigation; but in those times knowledge was not, and could not, owing to difficulties of intercommunication, the dearness of books, the costliness or the non-existence of instiuments, have been increased at the rate at which it is now being, year by year, increased; and the entire mass of actually existiin and acquired knowledge was of course much smaller, though man's power of mastering it was no smaller than at present. It would now be an indication of very great ignorance in anybody which should pretend that his own stock of information could furnish him with something in each one of the several departments of knowledge I have just mentioned, which should be worthy of being laid before such an assembly as this. As will have been expected, I shall not presume to do more than glance at the vegetable kingdom, large as is the space in the landscape of life which it makes. What I do propose to do is merely to draw your attention to a very few of the topics of leading interest, which are at the present moment being, or rather will shortly begin to be, discussed by experts in the Department of Physiology and Anatomy ; in the Department of Ethnology and Anthropology; and thirdly, in the Department of Scientific Zoology.

Under the head and in the Department of Physiology Proper and Anatomy, our list of papers and, I am happy to add, the circle of faces around us suggests to us the following subjects as being the topics of main interest for the present year : the questions of Spontaneous Generation; that of the infuence of organised particles in the production of disease; that of the influence of particular nervous and chemical agencies upon functions; that of the localisation of cerebral functions; that of the production and indeed of the entire role in the economy of creation of such substances as fat and albumen; and, fimally, that of the cost at which the work of the animal machine is carried on.

The question of Spontaneous Generation touches upon certain susceptibilities which lie outside the realm of science. In this place, however, we have to do only with scientific arguments, and I trust that the Section will support the Committee in their wish to exclude from our discussions all extraneous considerations. Truth is one ; all roads which really lead to it will assuredly converge sooner or later; our business is to see that the one we are ourselves concerned with is properly laid out and metalled.

Upon this matier I am glad to be able to fortify myself by two authorities; and furst of these I will place an utterance of Archbishop Whately, which may be found in the second volume of his Life, pp. 66-68, æt. 57, an. I844. "A person possessing real faith will be fully convinced that whatever suppressed physical fact appears to militate against his religion will be proved by physical investigation either to be unreal or else reconcilable with his religion. If I were to found a church, one of my articles would be that it is not allowable to bring forward Scripture or any religious considerations at all to prove or disprove any physical theory or any but religious and moral considerations." My second quotation shall be taken from the great work of one of the fixst, as I apprehend, of living theologians, John Macleod Campbell, "The Nature of the Atonement," pp. xxxii.-xxxiii. Introd, , and it runs thus :- There are "other-minds whose habits of pure scientific investigation are to them a temptation to approach the claim of the Kingdom of God on our faith by a wrong path, causing them to ask for a kind of evidence not proper to the subject, and so hindering their weighing fairly what belongs to it. No scientific study of the phenomena which imply a reign of law could ever have issued in the discovery of 
the kingrlom of God. But neither can it issue in any discovery which contradicts the existence of that kingdom; nor can any mind in the light of the kingdom of God hesitate to conclude that if such seeming contradictions arise there is implied the presence of error either as to the facts or as to conclusions from the facts." These are valuable words and weighty testimonies. But in a matter of this importance one must not forbear to point out what may seem to be wanting even in the dicta of such men as the two I have quoted. Neither of them have allowed the possibility of error attaching itself to the utterances of more than one of the two parties in such issues as those contemplated. Neither appears to have thought of the cases in which religious men, if not theologians, have brought war on the world because of the offences they have with ill-considered enunciations created. And, whilst fully sympathising with all that the Archbishop and Mr. Campbell have said, I must say that they appear to me to have left something unsaid, and this something may be wrapped up in the caution that there may be faults on both sides. But at any rate this Section cannot be considered a fit place for the correction of errors save of the physical kind; and all other considerations are for this week and in this place extraneous. In some other week or in some other place it will be, if it has not already been, our dnty to give them our best attention.

To come now to the kind of considerations which are the proper business of Section D, let me say that for the discussion of the question of Spontaneous Generation very refined means of observation, and, besides these, very refined means of experimentation, are necessary. And I shall act in the spirit of the advice I have already alluded to as given to the world by one of her greatest teachers, if I put before you a simple but a yet undecided question for the solution of which analogons means of a far less delicate character would appear to be, but as yet have not proved themselves to be, sufficient. Thus shall we come to see very plainly some of the bearings, and a few of the difficulties, of the more difficult of the two questions. What an uneducated person might acquiesce in hearing spoken of as Spontaneous Generation, takes place very constantly under our very eyes, when a plot of ground which has for many years, or even generations, been devoted to carrying some particular vegetable growth, whether grass or trees, has that particular growth removed from it. When such a clearing is effected, we often see a rich or even a rank vegetation of a kind previously not growing on the spot spring up upon it. The like phenomenon is often to be noted on other surfaces newly exposed, as in railway cuttings and other escarpments, and along the beds of canals or streams, which are laid bare by the turning of the water out of its channel. Fumitory, rocket, knotgrass, cowgrass, Polygonum aviculare, and other such weeds, must often have been noted by every one of us here in England as coming into and occupying such recently disturbed territories in force; whilst in America the destruction of a forest of one kind of wood, such as the oak or the chestnut, have often been observed to be followed by an upgrowth of young forest trees of quite another kind, such as the white pine, albeit no such tree had been seen for generations growing near enough to the spot to make the transport of its seeds to the spot seem a likely thing. In one case referred to by Mr. Marsh, the hickory, Carya porcenta, a kind of walnut, was remarked as succeeding a displaced and destroyed plantation of the white pine. Now the advocates of Spontaneous Generation must not suspect me of hinting that there is any question, except in the minds of the grossly ignorant, of the operation of any such agency as spontaneous generation here; no one would suggest that the seeds of the Polygonum aviculare, to say nothing of those of the Hickory, were produced spontaneously; but what I do say is, that the question of how those seeds came there is just the very analogue of the one which they and their opponents have to deal with. And it is not definitely settled at this very moment. Let us glance at the instructive historical parallel it offers. For the very gross and palpable facts of which I have just spoken there are two explanations offered in works of considerable authority. The one which has perhaps the greatest currency and commands the largest amount of acceptance is the one which, in the words of De Candolle, regards la couche de terre végétale d'un pays comme un magazin de graines, and supposes that in hot summers and autumns, such as the present, the fissures in the ground, which have proved so fatal this year to the young partridges, swallow up a multitude of seeds, which are restored again to life when the deep strata into which they are thus introduced, and in which they are sealed up as the chasms close up, come in any way to be laid open to the unimpeded action of the sun and moisture.
Squirrels, again, and some birds resembling herein the rodent mammalia, bury seeds and forget to dis them up agnin; and it is supposed that they may bury them so deep as to be protected from the two physical agencies just mentioned. Now Germination cannot take place in the absence of oxygen, and I would add that well-sinkers know to their cost how often the superficial strata of the earth are surcharged with carbonic acid. The rival explanation and the less popular-I do not say the less scientific-looks to the agency of transportation as occurring constantly, and sufficing to explain the facts. By accepting this explanation, we save ourselves from running counter to certain experiments, some of which were carried out, if I mistake not, under the auspices of this Section (see British Assoc. Reports), and which appear to curtail considerably the time during which seeds retain their vitality, and to multiply considerably the number of conditions which must be in force to allow of such retention for periods far shorter than those which have to be accounted for. A better instance of the expediency of checking the interpretations based merely upon observations however accurately made by putting into action experiments, cannot be furnished than by recording the fact put on record by $\mathrm{Mr}$. Bentham, when discussing this question in his last year's address to the Linnetan Society. "Hitherto direct observation has, as far as I am aware, only produced negative resilts, of which a strong instance has been communicated to me by Dr. Hooker. In deepening the lake in Kew Gardens, they uncovered the bed of an old piece of water, upon which there came up a plentiful crop of Typhs, a plant not. observed in the immediate vicinity; and it was therefore concluded that the seed must have been in the soil. To try the question, Dr. Hooker had six Ward's cases filled with some of the soil remaining uncovered close to that which had produced the Typha, and carefully watched; but not a single I'ypha came up in any one of them." (Note in President's address May 24th, 1869, page 72 of Linnæan Society's Proceedings.)

To this I would add that experiments with a positive résult, and that positive result in favour of the second hypothesis, if hypothesis it can be called, are being constantly tried in our colonies for us, and on a large scale. I had taken and written here of the Polygonum aviculare, the "knot" or "cowgrass"-having learnt on the authority of Dr. Hooker and Mr. Travers (see Natural History Review, January 1864, p. 124, Oct. 1864, p. 619), that it abounds in New Zealand, along the roadside, just as it does in England-as a glaring instance, and one which would illustrate the real value of the second explanation even to an unscientific man and to an unassisted eye. But on Saturday last I received by post one of those evidences which make an Englishman proud in thinking that whithersoever ships. can float thither shall the English language, English manners, and English Science be carried, in the shape of the second volume of the Transactions of the New "Zealand Institute, full like the first, from beginning to the last page with thoroughly good matter. In that volume, having looked at its table of contents, I turned to a paper by Mr. T. Kirk on the Naturalized Plants of New Zealand, and in this, at p. ${ }^{4} 2, I$ find that Mr. T. Kirk prefers to regard the Polygonum aviculare of New Zealand as indigenous in New Zealand. Hence that illustration which would have been a good one falls from my hands. And I must in fairness add, that because one agency is proved to be a vera causa, it is not thereby proved that no other can by any possibility be competent simultaneously to produce the same effect, whatever the Schoolmen with the law of Parsimony ringing in their ears may have said to the contrary. I have dwelt upon this subject at this length with the purpose of showing how much difficulty may beset the settlement of even a comparatively simple question which involves only the use of the unassisted eye, or at most of a simple lens. The a fortiori argument, I leave you to draw for yourselves with the simple remark, that the question of Spontaneous Generation is now at least one to be decided by the microscope, and by the employment of its highest powers in alliance with other apparatus of all but equal complexity.

We come, in the second place, to say a word as to the extent of the influence which organic and living particles, of microscopic minuteness but solid for all that, have been supposed, and in some instances at least have been proved, to exercise upon the genesis and genesiology of disease, and so upon the fortunes of our race, and our means for bettering our condition, and that of our fellows. I need not refer to Dr. Sanderson's valuable Report (just published in the Privy Council's Medical Officer's Blue Book, Twelfth Report, I870, p. 229, upon those contagion particles which he proposes to call by the convenient name, slightly modi- 
fied from one invented by Professor Bichamp, of Microzymes; for Dr. Sanderson is here to refer to the matter for himself and for us; and when this meeting is over we shall all do well to lay to heart what he may tell us here and now, and besides this, to study his already printed views upon the matter. It may be perhaps my business to remind you that these views, so far as they are identical with Professor Halliers' as to the importance of those most minute of living organisms, the micrococcus of his nomenclature, the microzymes of $\mathrm{Mr}$. Simon's Blue Book, were passed in review as to their botanical correctness by a predecessor of mine in this honourable office - namely, by the Rev. J. M. Berkeley, at the meeting held two years ago at Norwich; and that some of the bearings of the theory and of the facts, howsoever interpreted, upon the Theory of Evolution, were touched upon by Dr. Child in his interesting volume of Physiological Essays, p. I48, published last year. It would not perhaps be exactly my business to express my dissent from any of these results or views put forward by any of these investigators I have mentioned; but I wish to point out to the general public that none of these inquirers would affirm that the agencies shown by them to be potent in the causation of certain diseases were types and models of the agencies which are, did we but know it, could we but detect them, potent in the causation of all diseases. Many diseases, though possibly enough not the majcrity of the strictly infectious diseases, are due to material agents quite distinct in nature from any self-multiplying bodies, cytoid or colloid. To say nothing of the effects of certain elements-and elements, it will be recollected, in their singleness and simple atomicity have, as the world happens to be constituted and governed, never been honoured with the office of harbouring lifewhich when volatised, as mercury, arsenic, and phosphorus may be, or indeed which, when simply dissolved, may be most ruinous to life, there are, I make no doubt, animal poisons produced in and by animals, and acting upon animal bodies which are neithex organised nor living, neither cytoid nor colloid. Dr. Charlton Bastian is not likely to underrate the importance of such agents, howsoever produced, in the economy, or rather in the waste, of Nature, yet from his very careful record of his own very closely observed and personal experience we can gather that he would not demur to conceding that non-vitalised, however much animalised, exhalations may be only too powerful in producing attacks, and those sudden and violent and fever-like attacks, of disease. Dr. Bastian tells us (Phil. Trans. for I866, vol. 196, pt. ii. pp. $583-584$ ) that whensoever he employed himself in the dissection of a particular nematoid worm, the Ascaris megalociphala, he found occasion to observe, and that in himself, and very closely, the genesiology of a spasmodic and catarrhal affection, not unlike hay-fever as it seems to me, but under circumstances which appear to preclude the possibility of any living organisms being the cause of it as they have been supposed, and by no less an authority than Helmholtz, to be of the malady just mentioned. For in Dr. Bastian's case this affection was produced, not only when the Ascaris megalocephala was dissected when fresh, but "after it had been preserved in methylated spirit for two years, and even then macerated in a solution of chloride of lime for several hours before it was submitted to examination." Could any microzyme or megalozyme have survived such an amount of antizymotic treatment-such a pickling as this? This is not exactly a medical association, and I have entered upon this discussion not altogether without a wish to show how subjects of apparentily the most purely scientific and special interest, as $\mathrm{My}$ cology and Helminthology, the natural history, that is to say, and the morphology of the lowest plants and of the lowest vermes, may come when we least expect it, come or be brought to bear upon matters of the most immediate and pressing practical importance. And in this spirit I must say a word upon the way in which the pathology of snake-bites bears upon the matters I have been speaking of, and the extent of the debt which practical men owe to such societies as our Ray Society, and to such publications as their colossal volume on the snakes of India, in which Dr. Giinther's views as to the real history of the striking and terrible yet instructive phenomena alluded to, are combined ("Snakes of India," Ray Society, 1864, p. 167). That the snake-poison is an animal poison is plain enough; that it is fatal to men and animals everybody knows; but $\mathrm{I}$ rather think that these two facts relative to it are not equally notorious, rich in light though they be, viz., that the potency of this particular animal poison varies in direct ratio to the quantity imbibed or infused, just as though it were so much alcohol, or so much alcoholic tincture of musk or cantharides; or secondly, that its potency varies in direct ratio to another varying standard, viz., the size of the animal producing it. Now, the vaccine matter from the arm of a child is as potent as the vaccine matter from the arm of any giant might be, if such a large creature could in these days escape the operation of the vaccination laws ; and whether a grain or a gramme of it be used, will make no difference, so long as it be used rightly. There is a contrast indeed between the modus operandi of these two animal poisons. I would add that in the Edinburgh Monthly Medical Fournal for the present month there is a very valuable paper, one of a series of papers, indeed, of the like character, by Dr. Fayrer, where at page 247 , among much of anatomical and other interest, I find the following important statement:"This poison may be diluted with water, or even ammonia or alcohol, without destroying its deadly properties. It may be kept for months or years, dried between slips of glass, and still retain its virulence. It is capable of absorption through delicate membranes, and therefore it cannot be applied to any mucous surfaces, though no doubt its virulence is much diminished by endosmosis. * It appears to act by a catalytic form; that is it kills by some occult influence on the nerve centres." There is such a thing as an ignorance which is wiser than knowledge, for the time, of course, only; such an ignorance is wisely confessed to in these words of Dr. Fayrer's:- An explanation may be true for some, yet not thereby necessarily for all, the facts within even a single sphere of study, even a true explanation may have but a very limited application, as a tangent cannot touch a circle at more than a single point. The memoirs, published in our own reports by Dr. R. W. Richardson, on the action of the nitrites, and those published by Dr. A. Crum Brown and Dr. Fraser, there and elsewhere, on the connection between chemical constitution and physiological action, deserve especial study as bearing on the other side of this discussion ; whilst Prof. Lister's papers show how the reference of certain diseases to inhalistic agencies may become o most useful importance in practice. There exists, as is wel known, a tendency to involve all Physiological into Physicochemical phenomena; undoubtedly many have been, and some more may still remain, to be so ordered, but the public may rest assured that in the kingdom of Biology no desire for a rectification of frontiers will ever be called out by any such attempts at, or successes in the way of, encroachment; and that where physics and chemistry can show that physico-chemical agencies are sufficient to account for the phenomena, there their claim upon the territory will be acceded to, as in the cases we have been glancing at; and where such claims cannot be established and fail to come up to the quantitative requirements of strict science, as in the cases of continuous and of discontinuous deveJopment or self-multiplication of a contagious germ, and in some others, they will be disallowed.

\section{(To be Continused.)}

Section E.-Geographical Science.-Sir Roderick Murchison, K.C.B., F.R.S., President.

In opening his address, after alluding to the more recent geo. graphical discoveries which had been made, and to the geographical expeditions now in progress in Asia and Africa, and of which a much fuller account is to be found in his recent address to the Greographical Society, the President passed on to the subject of Deep Sea Soundings and their relation to Geology. Here he said he dissented most strongly from the views held by Dr. Carpenter and others, that in a broad sense we may be said to be in the Cretaceous epoch, since so inany of the marine forms met with were similar to, if not identical with, those which lived at that time. Thus he says, "May we not indeed by a similar bold hypothesis affirm that we still live in the older Silurian period? for albeit no bony fishes then existed, many globigerina and creatures of the lowest organisation have been found in these old rocks associated with terebratulidæ and dingulæ, the genteric forms of which still live." Surely we need not point out to Sir Roderick Murchison that generic forms are one thing and identical species another, and that whilst the former are evidence of similarity of condition, the latter are evidence of i'ersistency of con: ditions. From this Sir Roderick passed to the subject of the Physical Geography of the Ocean, and paid a great compliment to the valuah!e work lately published by Mr. J. K. Laughton, on "Physical Geography in its Relation to the Prevailing Winds and

* Diapedesi may account fer what yirulence remains, ayd the poison may therefore possibly be a cytoid. 
Currents;" and after referring to the various papers about to be read to the Section, he concluded his address by expressing his conviction, founded on all recent information, that Dr. Livingstone was alive and amongst friendly natives, and that Sir Samuel Baker would shortly meet him with fresh stores of provisions, \&c.

SEction F. - Economic Science,-President, Prof. W. Stanley Jevons.

In the President's address, which was of some length, after some introdactory remarks, tending in show that the ticonomic Section has to deal with a class of subjects capable of strictly scientific treatment, and that the social are the necessary complement to the physical sciences, Professor Jevons proceeded to state that in this lingdom during the last thirty or forty years we had tried a mighty experiment, and to a great extent had failed. The growth of the arts and manufactures and the establishment of free trade had opened the widest means of employment, and brought an accession of wealth previously unknown; the frequent remission of taxes had left the working classes in fuller enjoyment of their wages; the poor laws had been reformed and administered with care, and the emigration of millions might well have been expected to leave room for those that remained. Nevertheless within the last few years we had seen pariperism almost as prevalent as ever, and the slightest relapse of trade threw whole towns and classes of people into a state of destitution little short of famine. This state of things was exactiy what Nialthus would have predicted of a population which, while supplied with easily earned wealth, is deprived of education and bribed by the mistaken benevolence of the richer classes into a neglect of the future. We now had an Education Act, but this ought not to withdraw attention fiom many other catises of evil still existing in full force. Amongst these was the mistaken htimanity of charitable people. The amount extended by the upper to the lower classes was almost incredible; but it did more harm than good. The helpless pon were most numerous precisely in those towns where charitable people and institutions most abounded. I3ut far worse than private charity were the innumerable small charities established by the bequests of mistaken testators. It would be well worthy of Mr. Gosclien's attention whether all such charities might not be transferred to the care of the guardians of the poor, so as to be brought under the supervision of the Poor Law Board, and distributed in accordance with somd principles. The State, which undertool the ultimate support of the poor, was bound to prevent its own efforts to rechuce pauperism from being frustrated, as they are at present. As regards medical charities, Professor Jevons said no one could for a moment propose to abolish hospitals and numerous institutions absolutely necessary for the relief of accidental suffering; but no working man was solvent who did not lay aside so much of his wages as would meet the average amount of sickness falling to the lot of the man and his family. So it was not easy to determine this amount. There were or might be sick clubs which would average the inequalities of life. Hospitals need not be self-supporting, and in cases of severe and unforeseen suffering they might give the most lavish aid; but they ought not to relieve sight and ordinary clisease without a contribution from those benefited. With respect to the Poor Law medical service, every one admitted that where medical aid is given it ought to be good and sufficient; but, on the other hand, the better we make that service the more do we tend to increase and perpetuate that want of self-reliance and providence which is the crowning defect of the poorer classes. In this and many other cases we ought to regulate our humane impulses by a stern regard to the real results of our actions. Referring to the financial policy of the lingdom, Professor Jevons pointed out that in Cobden's sense free trade is now actually achievel. For the future the remission of customs duties would be grouncled on other motives than it has often been in the past. It was a mistake to suppose that foreign tracle ought to be encouraged before everything else. The internal trade and industry of thic country were at least equally deserving of attention, and it might be that there were stamp chties, licence duties, rates, and other taxes which, in proportion to the revenue they returnerf, did far mise injury than any customs duties now remainiug. The citiestion of local taxation was one which especialiy required attention. The amount raised by local rates was more than cqual to the whole of the customs duties; nevertheless they continied to be levied substantially according to an Act passed in the reign of Queen Elizabetly. There was sure to be a con- tinzous increase of local taxation. Tuming to the question of suplus revenue, Professor Jevons said that there probably now existed no grievous pressure of taxation, and no considerable inequality as regards the several classes of the people. He calculated that average families spending $40 \%$. 85 l, and $500 l$. a year, consuming moderate quantities of tobacco and spirituous liquors, all paid about ro per cent. of their income in general or local taxation. Only the taxation of the middle classes was mostly unavoidable, whereas at least half the taxation of the poorer classes depended upon the amount of tobacco and spirituous liquors consumed. The present incidence of taxation, therefore, was such that it seemed inexpedient to proceed further in the reduction of the custorns and excise duties. To do so would be to throw the whole cost of Government upon the wealthier classes, and especially those who have tangible property. Besides, when really hurtful taxes were removed, the working classes were not sufficiently temperate and educated to render it certain that the further remission of taxes would lead to the profitable expenditure of income. The true channel for suxplus revenue was the reduction of the national debt. The wars at the commencement of this century had secured for us fifcy years or more of nearly unbroken peace, and yet at the end of this period of ever-advancing wealth the great debt stood almost at the same figure as at the beginning. We enjoyed the peace and left our clescenclants to pay its cost. If jt was said that this country is now far wealthier and better able to endure the ammual charge of the debt than ever before, it must be remembered that the expense of war is also grtealy increased. In a great war we should now have to incur an expenditure of hundreds of millions, or else relinquish our prominent position. In dealing with the subject of the excessive mortality in great towns, Prof. Jerons expressed his surprise that more attention had not been drawn to the probable influence of a poor Irish population in raising the death-rate, According to the census returns of $186 \mathrm{~T}$, the monhealthy towns of liverpool, Manchester, Salop, Glasgow, Dundee, \&c., were all distinguished by possessing a large Irish population, whereas the healthy towns of London, Birmingham, Bristol, Hull, Aberdeen, \&c., had less than $7 \frac{1}{2}$ per cent. of adult Irish resicients. Sheffield was the only remarkable exception to this indicated. Prof. Jevons referred to the approaching census of $187 \mathrm{I}$, as likely to afford many data for the investigations of economists, and insisted that it ought to be taken in as nearly as possible a uniform manner in all the three parts of the United Kingclom. He also directed attention to the copious and excellent statistical publications now provided by Govemment; referred to the efforts which were being macle, previous to the present war, to facilitate the aloption of an international currency; and conclucled with some remarks on the transference of the telegraphs to Govermment cont:ol. Many people looked forward to the time when the unifom cost of a telegram would be $6 d$. ; but such a reduction of the rate, by bringing an increase of work, would greatly augment the expenses of the deparment, and infict a loss upon the nation.

\section{CONTENTS}

PAGE

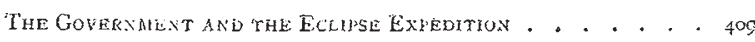

Refly to Prof. Hácxlev's Inaugtral Address at liverrool on THE Question uf the Origin Ol Life. By Dr. H. Charlton BASTIAN, F.R.S.

LETTERS TO IHE EDTTOR:-

English Physiology,-Dr. P. M. LRAIDwood. . . . . . . 413

Mirage.-Rey. Canon Kingsley. . . . . . . . . 414

Astronomical Science.--T. S. Pribeaux ........ . 414

Insects upon a Swallow . . . . . . . . . . . 414

Norms. . . . . . . . . . . . . . . 414

The Blitish Assocharion,-Our Currespondent's Letter . . atr

Report of rill Council. . . . . . . . . . . . . . 448

Sectional Proceedings:--Secrion A.-Prof. J. Clerk Maxwell's

Address. Section D.-Papers by D. Forbes, F.R.S., and H. Deacon. Section C.-Papers by G. H. Morton, Dr. Ricketts, J. Thompson, W. H. Bailey, W. S. Mitchell, G. Maw, and Prof. Williamson. Section D.-Prof. Rolleston's Address. Section E.-Sir Roderick Murchison's Address. Section R.--Prof. W. Stanley Jevons's Address : . . . . . . . . 419-428 